\title{
Partition coefficients of some aromatic hydrocarbons and ketones in water, blood and oil
}

\author{
AKIO SATO AND TAMIE NAKAJIMA
}

From the Department of Hygiene, Shinshu University Faculty of Medicine, Asahi Matsumoto, 390 Japan

\begin{abstract}
Water/air, blood/air, oil/air, oil/water, and oil/blood partition (or solubility) coefficients of 17 aromatic hydrocarbons and ketones were measured by a newly developed vial-equilibration method, which needs no direct measurement of the concentration either in the liquid or in the air phase, but only the gas chromatographic peak heights of the air in the sample (in which a test material is contained) and reference vessels (containing no test material). It was found that the blood/ air partition coefficients for aromatic hydrocarbons are correlated closely with the product of water/ air and oil/air partition coefficients, whereas those for ketones are almost in the same range as the water/air, irrespective of the oil/air partition coefficients.
\end{abstract}

The solubility of a gas (or vapour) in a liquid is normally expressed by the partition coefficient $\lambda$. This is the ratio of the concentration of a gas in the liquid to that in the gas phase at equilibrium.

Simultaneous measurement of the concentration of volatile hydrocarbons in liquid and air is so difficult that a variety of methods have hitherto been devised to determine the partition coefficient (Powell, 1947; Morgan et al., 1970; van Rees, 1974; Sherwood, 1976). Some of them are tedious and often cause practical difficulties. We have recently developed a very simple method to determine the partition coefficient using a vial-equilibration technique in combination with gas chromatography, which has enabled us to determine the water/air, blood/air and oil/air partition coefficients of 10 aromatic hydrocarbons and 7 aliphatic ketones. The present method has a number of advantages over the previous partition measurements, the most important feature being that no direct measurement of the concentration either in the liquid or in the air phase is necessary. In addition, by selecting a gas chromatograph with an appropriate column and detector, we may be able to apply the method to almost all of the volatile hydrocarbons.

\section{Methods}

PRINCIPLE OF MEASUREMENT

The principle of the method is as follows. The test material (distilled water, blood or olive oil) is put in

Received for publication 31 August 1978

Accepted for publication 15 December 1978 a small vessel. A hydrocarbon in an amount small enough to be evaporated completely in the vessel is then added. The vessel is made airtight and kept at a known temperature to establish the equilibrium of the hydrocarbon between the test material and the overlying air. After equilibration the concentration of the hydrocarbon in the air phase is measured. As the quantity of hydrocarbon within the system is unchanged, the concentration in the liquid phase and consequently the partition coefficient can be calculated from the concentration in the air phase. When measurements are carried out with two separate samples, the hydrocarbon concentrations in their air phases relate to each other as the partition coefficients of the two test materials.

Two equilibration vessels (sample and reference vessels), volume $\mathrm{V}$, are required. A test material, volume $T$, is put into one vessel (sample vessel), while the other (reference vessel) is kept empty. A known volume $S$ of a water solution of hydrocarbon (its exact concentration is not important, but the lower the better) is pipetted into each of the two vessels, which are then closed and kept at a known temperature. In the sample vessel the hydrocarbon is partitioned between the water, volume $S$, the test material, volume $T$, and the air phase, volume $\mathrm{V}-\mathrm{S}-\mathrm{T}$, finally reaching equilibrium. The total quantity, $\mathrm{q}$, of the hydrocarbon in the system is conserved, hence we obtain,

$$
\mathrm{q}=\mathrm{y}_{1}(\mathrm{~V}-\mathrm{S}-\mathrm{T})+\mathrm{y}_{1} \lambda_{\mathrm{A}} \mathrm{S}+\mathrm{y}_{1} \lambda_{\mathrm{T}} \mathrm{T},
$$

where $y_{1}$ is the equilibrium concentration in the air phase, $\lambda_{\mathrm{A}}$ the partition coefficient between water and 
air, and $\lambda_{T}$ that between test material and air.

In the reference vessel, on the other hand, the hydrocarbon, quantity $\mathrm{q}$, is partitioned between the aqueous phase, volume $S$, and the air, volume $V-S$. Let $y_{2}$ be the concentration in the air phase of this vessel, then the following equation holds:

$$
\mathrm{q}=\mathrm{y}_{2}(\mathrm{~V}-\mathrm{S})+\mathrm{y}_{2} \lambda_{\mathrm{A}} \mathrm{S}
$$

From (1) and (2),

$$
\frac{\substack{\lambda_{T}=\\ y_{2}(V-S)-y_{1}(V-S-T)+\left(y_{2}-y_{1}\right) \lambda_{A} S}}{y_{1} T}
$$

When a sharp peak is obtained from injection of a fixed volume of the air phase into a gas chromatograph, its height is proportional to the concentration in the air phase. If $h_{1}$ is the peak height obtained from the air in the sample vessel and $h_{2}$ the one from the reference vessel, then we have,

$$
\mathrm{y}_{1}=\mathrm{kh}_{1} \text { and } \mathrm{y}_{2}=\mathrm{kh}_{2}
$$

where $\mathbf{k}$ is a constant depending on each hydrocarbon. Hence equation 3 can be rewritten as follows:

$$
\frac{\stackrel{\lambda_{T}=}{h_{2}(V-S)-h_{1}(V-S-T)+\left(h_{2}-h_{1}\right) \lambda_{A} S}}{h_{1} T}
$$

When the test material is water (in this case, $\lambda_{\mathbf{T}}=\lambda_{\mathbf{A}}$ ), equation 5 is also rewritten as follows:

$$
\lambda_{\mathrm{A}}=\frac{\mathrm{h}_{2}(\mathrm{~V}-\mathrm{S})-\mathrm{h}_{1}(\mathrm{~V}-\mathrm{S}-\mathrm{T})}{\mathrm{h}_{1}(\mathrm{~S}+\mathrm{T})-\mathrm{h}_{2} \mathrm{~S}}
$$

It is clear from (5) and (6) that the partition coefficients can be calculated from the gas chromatographic peak heights of the air in the sample and reference vessels. Once the water/air, blood/air and oil/air partition coefficients are obtained, the oil/blood partition coefficient can be calculated as (oil/air)/(blood/air), and the oil/water as (oil/air)/ (water/air).

\section{MEASUREMENT PROCEDURES}

Twenty glass vials with a plastic screw cap, internal volume $16.5 \mathrm{ml}$, were used as the equilibration vessels. An opening of $1 \mathrm{~cm}$ in diameter was made in the cap. The inner cover of the cap was made of rubber sheeting to fit the cap, and aluminium foil of the same size was attached to its lower surface as a seal. These vials were divided into four groups each of five vials. Each vial of the first group con- tained $1.0 \mathrm{ml}$ of distilled water, each of the second group contained $1.0 \mathrm{ml}$ of blood, and each of the third contained approximately $0.1 \mathrm{ml}$ of olive oil (the exact volume was calculated from the specific gravity after measuring the weight). The vials of the last group were kept empty. One tenth of a ml of a water solution of a hydrocarbon, at a concentration of $5-10 \mu \mathrm{l} / 100 \mathrm{ml}$, was added to each vial of all the groups. All the vials were allowed to stand in a thermoregulated water bath with a shaker at $37^{\circ} \mathrm{C}$ for 0.5-2 hours to establish the equilibrium (Sato et al., 1975). When the equilibrium was reached, $1.0 \mathrm{ml}$ of the air in the vial was withdrawn through its rubber and aluminium foil septum into an airtight syringe, and injected into a gas chromatograph with a hydrogen flame ionisation detector, the operating conditions of which were as follows: column, $2 \mathrm{~m}$ PEG 400 or SE-30 each at $80^{\circ} \mathrm{C}$; carrier gas, $\mathrm{N}_{2}$ at $70 \mathrm{ml} / \mathrm{min} ; \mathrm{H}_{2}, 20 \mathrm{ml} / \mathrm{min}$. The partition coefficients were calculated using the mean values of peak heights by means of equations 5 and 6 .

We used preserved blood purchased from a blood bank, containing $13 \%(\mathrm{v} / \mathrm{v})$ of blood-preserving solution $(2.2 \mathrm{~g}$ sodium citrate, $0.8 \mathrm{~g}$ citric acid and $2.2 \mathrm{~g}$ glucose in $100 \mathrm{ml}$ ). Olive oil was reagent grade. The measurements were made after it had been confirmed that the gas chromatographic response (peak height) was linearly related to the gas phase concentration.

\section{Results and discussion}

The partition coefficients of water/air, blood/air, olive oil/air, olive oil/water, and olive oil/blood determined for 10 aromatic hydrocarbons and 7 ketones are listed in the Table.

The present blood/air partition coefficients for benzene, toluene and $m$-xylene agree well with those which were determined by Sato et al. (1972) using large vials $(150 \mathrm{ml})$ as the equilibration vessels, which contained $10 \mathrm{ml}$ of freshly sampled blood and $1 \mu \mathrm{l}$ of the liquid hydrocarbons. They are also fairly consistent with those obtained by Sherwood (1976) using the blood-adsorbed column as a gas chromatographic column and applying the resultant retention volume to the equation of Lowe and Hagler (1969).

With regard to styrene, van Rees (1974) reported the water/air, blood/air and olive oil/air partition coefficients to be $4 \cdot 38,32$ and 4100 , respectively. The water/air partition coefficient is in general agreement with ours, but the blood/air and olive oil/air, especially the former, are not. The differences are too great to be expected from the difference in the composition of blood used (van Rees used freshly sampled blood, whereas we used preserved blood). 
Table Partition coefficients at $37^{\circ} \mathrm{C}$

\begin{tabular}{|c|c|c|c|c|c|c|}
\hline \multirow[t]{2}{*}{ Chemicals } & \multirow[t]{2}{*}{ Structure } & \multicolumn{5}{|c|}{ Partition coefficients } \\
\hline & & $\lambda_{\mathrm{A}}$ & $\lambda_{\mathbf{B}}$ & $\lambda_{\mathrm{c}}$ & $\lambda_{\mathbf{C}} / \lambda_{\mathbf{A}}$ & $\lambda_{C} / \lambda_{B}$ \\
\hline Benzene & $\mathrm{C}_{6} \mathrm{H}_{6}$ & $\begin{array}{l}2 \cdot 78 \\
(0 \cdot 30)\end{array}$ & $\begin{array}{c}7 \cdot 8 \\
(1 \cdot 1)\end{array}$ & $\begin{array}{l}492 \\
(24)\end{array}$ & 177 & 63 \\
\hline Toluene & $\mathrm{C}_{6} \mathrm{H}_{5} \mathrm{CH}_{3}$ & $\begin{array}{l}2 \cdot 23 \\
(0 \cdot 16)\end{array}$ & $\begin{array}{l}15 \cdot 6 \\
(1 \cdot 7)\end{array}$ & $\begin{array}{l}1471 \\
(69)\end{array}$ & 659 & 94 \\
\hline Ethylbenzene & $\mathrm{C}_{6} \mathrm{H}_{5} \mathrm{CH}_{2} \mathrm{CH}_{3}$ & $\begin{array}{r}1.69 \\
(0 \cdot 18)\end{array}$ & $\begin{array}{l}28 \cdot 4 \\
(1 \cdot 7)\end{array}$ & $\begin{array}{l}3791 \\
(300)\end{array}$ & 2243 & 133 \\
\hline Propylbenzene & $\mathrm{C}_{6} \mathrm{H}_{5} \mathrm{CH}_{2} \mathrm{CH}_{2} \mathrm{CH}_{3}$ & $\begin{array}{l}1.30 \\
(0.07)\end{array}$ & $\begin{array}{l}47 \cdot 0 \\
(2 \cdot 4)\end{array}$ & $\begin{array}{l}9775 \\
.(486)\end{array}$ & 7519 & 208 \\
\hline$o$-Xylene & $\mathrm{C}_{6} \mathrm{H}_{4}\left(\mathrm{CH}_{3}\right)_{2}$ & $\begin{array}{l}2 \cdot 63 \\
(0 \cdot 32)\end{array}$ & $\begin{array}{l}31 \cdot 1 \\
(2 \cdot 3)\end{array}$ & $\begin{array}{l}4360 \\
(202)\end{array}$ & 1658 & 140 \\
\hline$m$-Xylene & $\mathrm{C}_{6} \mathrm{H}_{4}\left(\mathrm{CH}_{3}\right)_{2}$ & $\begin{array}{l}1 \cdot 66 \\
(0 \cdot 24)\end{array}$ & $\begin{array}{l}26 \cdot 4 \\
(0 \cdot 9)\end{array}$ & $\begin{array}{l}3842 \\
(187)\end{array}$ & 2314 & 146 \\
\hline$p$-Xylene & $\mathrm{C}_{6} \mathrm{H}_{4}\left(\mathrm{CH}_{3}\right)_{2}$ & $\begin{array}{l}1.57 \\
(0.36)\end{array}$ & $\begin{array}{l}37 \cdot 6 \\
(3 \cdot 5)\end{array}$ & $\begin{array}{l}3694 \\
(240)\end{array}$ & 2353 & 98 \\
\hline Cumene & $\mathrm{C}_{6} \mathrm{H}_{5} \mathrm{CH}\left(\mathrm{CH}_{3}\right)_{2}$ & $\begin{array}{l}1.44 \\
(0.06)\end{array}$ & $\begin{array}{l}37 \cdot 0 \\
(1 \cdot 3)\end{array}$ & $\begin{array}{l}6215 \\
(463)\end{array}$ & 4316 & 168 \\
\hline Styrene & $\mathrm{C}_{8} \mathrm{H}_{5} \mathrm{CH}=\mathrm{CH}_{2}$ & $\begin{array}{l}4 \cdot 68 \\
(0 \cdot 31)\end{array}$ & $\begin{array}{l}51.9 \\
(2.0)\end{array}$ & $\begin{array}{l}5465 \\
(219)\end{array}$ & 1168 & 105 \\
\hline Allylbenzene & $\mathrm{C}_{8} \mathrm{H}_{5} \mathrm{CH}_{2} \mathrm{CH}=\mathrm{CH}_{2}$ & $\begin{array}{c}3 \cdot 55 \\
(0 \cdot 18)\end{array}$ & $\begin{array}{l}50 \cdot 9 \\
(3 \cdot 1)\end{array}$ & $\begin{array}{l}8049 \\
(422)\end{array}$ & 2267 & 158 \\
\hline Acetone & $\mathrm{CH}_{3} \mathrm{COCH}_{3}$ & $\begin{array}{l}395 \\
(49)\end{array}$ & $\begin{array}{l}245 \\
(32)\end{array}$ & $\begin{array}{c}86 \\
(17)\end{array}$ & $0 \cdot 2$ & 0.4 \\
\hline Methyl ethyl ketone & $\mathrm{CH}_{3} \mathrm{COCH}_{2} \mathrm{CH}_{3}$ & $\begin{array}{l}254 \\
(29)\end{array}$ & $\begin{array}{l}202 \\
(10)\end{array}$ & $\begin{array}{l}263 \\
(21)\end{array}$ & $1 \cdot 0$ & $1 \cdot 3$ \\
\hline $\begin{array}{l}\text { Methyl propyl ketone } \\
\text { (2-Pentanone) }\end{array}$ & $\mathrm{CH}_{3} \mathrm{COCH}_{2} \mathrm{CH}_{2} \mathrm{CH}_{3}$ & $\begin{array}{l}166 \\
(14)\end{array}$ & $\begin{array}{l}150 \\
(12)\end{array}$ & $\begin{array}{l}626 \\
(28)\end{array}$ & $3 \cdot 8$ & $4 \cdot 2$ \\
\hline $\begin{array}{l}\text { Diethyl ketone } \\
\text { (3-Pentanone) }\end{array}$ & $\mathrm{CH}_{3} \mathrm{CH}_{2} \mathrm{COCH}_{2} \mathrm{CH}_{3}$ & $\begin{array}{l}181 \\
(22)\end{array}$ & $\begin{array}{l}168 \\
(6)\end{array}$ & $\begin{array}{l}808 \\
(43)\end{array}$ & $4 \cdot 5$ & $4 \cdot 8$ \\
\hline $\begin{array}{l}\text { Methyl n-butyl ketone } \\
\text { (2-Hexanone) }\end{array}$ & $\mathrm{CH}_{3} \mathrm{COCH}_{2} \mathrm{CH}_{2} \mathrm{CH}_{2} \mathrm{CH}_{3}$ & $\begin{array}{r}111 \\
(5)\end{array}$ & $\begin{array}{c}127 \\
(7)\end{array}$ & $\begin{array}{c}1635 \\
(64)\end{array}$ & 15 & 13 \\
\hline Methyl isobutyl ketone & $\mathrm{CH}_{3} \mathrm{COCH}_{2} \mathrm{CH}\left(\mathrm{CH}_{3}\right)_{2}$ & $\begin{array}{l}79 \\
(9)\end{array}$ & $\begin{array}{l}90 \\
(11)\end{array}$ & $\begin{array}{l}926 \\
(54)\end{array}$ & 12 & 10 \\
\hline $\begin{array}{l}\text { Methyl pentyl ketone } \\
\text { (2-Heptanone) }\end{array}$ & $\mathrm{CH}_{3} \mathrm{COCH}_{2} \mathrm{CH}_{2} \mathrm{CH}_{2} \mathrm{CH}_{2} \mathrm{CH}_{3}$ & $\begin{array}{l}96 \\
(9)\end{array}$ & $\begin{array}{l}199 \\
(24)\end{array}$ & $\begin{array}{l}6791 \\
(112)\end{array}$ & 71 & 34 \\
\hline
\end{tabular}

$\lambda_{\mathbf{A}}=$ water/air partition coefficient; $\lambda_{\mathrm{B}}=$ blood/air partition coefficient; $\lambda_{\mathrm{C}}=$ oil/air partition coefficient; $\lambda_{\mathrm{C}} / \lambda_{\mathrm{A}}=$ oil/water partition coefficient; $\lambda_{\mathrm{C}} / \lambda_{\mathrm{B}}=$ oil/blood partition coefficient.

Figures in parentheses in the columns $\lambda_{A}, \lambda_{B}$ and $\lambda_{C}$ are standard deviations of 5 measurements.

The reason for these differences has not yet been elucidated.

In the case of aromatic hydrocarbons, the blood/air partition coefficient, one of the most important factors controlling the uptake of inhaled organic solvent vapours (Morgan et al., 1970, 1972; Sato

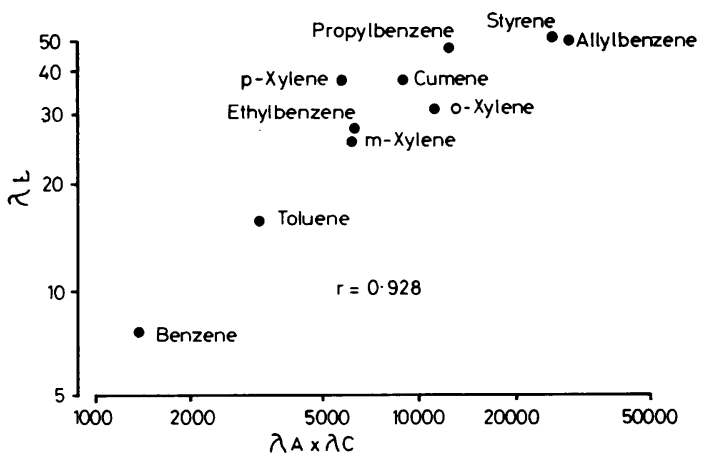

Figure Relationship between the blood/air partition coefficient $\left(\lambda_{\mathrm{B}}\right)$ and the product of the water/air $\left(\lambda_{\mathrm{A}}\right)$ and oil/air $\left(\lambda_{\mathrm{C}}\right)$ partition coefficients. et al., 1974; Åstrand, 1975), was found to be correlated closely with the product of water/air and oil/air partition coefficients on a log-log scale $(r=$ $0.93 ; n=10$ ) (see the Figure). On the other hand, the blood/air partition coefficients for ketones other than methyl pentyl ketone were almost in the same range as the water/air irrespective of the oil/air partition coefficients.

Partition coefficients of biologically active compounds between blood and air, oil and air, and between oil and water have been used widely and frequently for the study of structure-activity relationships. Miller et al. (1972) have reported that there is a linear relationship between the $\mathrm{ED}_{50}$ and olive oil/air partition coefficients of 20 narcotics of various types such as xenon, ether, chloroform etc. The similar linear relationship between the minimum alveolar concentration required to produce anaesthetic effects and olive oil/air partition coefficient for seven anaesthetics has also been pointed out by Eger rt al. (1965). Morgan et al. (1970) have reported that there is an obvious linear relationship between the anaesthetic potency and serum/air partition 
coefficient for nine chlorinated aliphatic hydrocarbons. Therefore, it can be said with certainty that the narcotic action of organic solvent vapours is dependent to some extent on their blood/air and oil/air partition coefficients. For example, for methylbenzene derivatives, the relative narcotic potency is expected to be in the order of xylene $>$ toluene $>$ benzene.

However, as pointed out by Morgan et al. (1972), a close correlation between the partition coefficient and a biological response does not necessarily mean that a substance which has the largest partition coefficient has the highest toxic potency. Some specific toxicities are known to be caused not by the parent substance itself but by its active metabolites produced in the course of metabolism, for example haematopoietic disorders in the case of chronic benzene poisoning (Gillette et al., 1974).

\section{References}

Åstrand, I. (1975). Uptake of solvents in the blood and tissues of man. A Review. Scandinavian Journal of Work, Environment and Health, 1, 199-218.

Eger, E. I. II, Brandstater, B., Saidman, L. J., Regan, M. J., Severinghaus, J. W., and Munson, E. S. (1965). Equipotent alveolar concentrations of methoxyflurane, halothane, diethyl ether, fluroxene, cyclopropane, xenon and nitrous oxide in the dog. Anesthesiology, 26, 771-777.

Gillette, J. R., Mitchell, J. R., and Brodie, B. B. (1974). Biochemical mechanisms of drug toxicity. Annual Review of
Pharmacology, 14, 271-288.

Lowe, H. L., and Hagler, K. (1969). Determination of volatile anaesthetics in blood, gases, tissues and lipids. Partition coefficients. In Gas Chromatography in Biology and Medicine, pp. 86-112. Edited by R. Porter. Churchill: London.

Miller, K. W., Paton, W. D. M., Smith, E. B., and Smith, R. A. (1972). Physicochemical approaches to the mode of action of general anesthetics. Anesthesiology, 36, 339-351.

Morgan, A., Black, A., and Belcher, D. R. (1970). The excretion in breath of some aliphatic halogenated hydrocarbons following administration by inhalation. Annals of Occupational Hygiene, 13, 219-233.

Morgan, A., Black, A., and Belcher, D. R. (1972). Studies on the absorption of halogenated hydrocarbons and their excretion in breath using ${ }^{38} \mathrm{Cl}$ tracer techniques. Annals of Occupational Hygiene, 15, 273-282.

Powell, J. F. (1947). Solubility or distribution coefficient of trichloroethylene in water, whole blood and plasma. British Journal of Industrial Medicine, 4, 233-236.

Sato, A., Fijiwara, Y., and Hirosawa, K. (1972). Solubility of benzene, toluene and m-xylene in blood. Japanese Journal of Industrial Health, 14, 3-8. (In Japanese.)

Sato, A., Nakajima, T., Fujiwara, Y., and Hirosawa, K. (1974). Pharmacokinetics of benzene and toluene. Internationales Archiv für Arbeitsmedizin, 33, 169-182.

Sato, A., Nakajima, T., and Fujiwara, Y. (1975). Determination of benzene and toluene in blood by means of a syringeequilibration method using a small amount of blood. British Journal of Industrial Medicine, 32, 210-214.

Sherwood, R. J. (1976). Ostwald solubility coefficients of some industrially important substances. British Journal of Industrial Medicine, 33, 106-107.

van Rees, H. (1974). The partition coefficients of styrene between blood and air and between oil and blood. Internationales Archiv für Arbeitsmedizin, 33, 39-47. 